\title{
The Constitutional Court of Albania and the Challenge for Its Functioning after the Constitutional Reform of 2016
}

\author{
Dr. Ismail Tafani \\ Head and Lecturer, \\ Department of Legal Sciences, \\ Albanian University, Albania \\ Prof. Asoc. Dr. Ervin Karamuço \\ Lecturer, Faculty of Law, \\ University of Tirana, Albania
}

DOI: https://doi.org/10.36941/ajis-2021-0057

\begin{abstract}
This study aims to address the functioning and cooperation of constitutional bodies in the Republic of Albania. It aims to highlight the often-rigid relationship between them for the establishment of constitutional bodies, especially when this process needs to pass through a spirit of cooperation. More specifically, the paper will refer to the lack of functioning of the Constitutional Court in the Republic of Albania. This lack, without question, has brought a problem in the functioning and consolidation of the rule of law in the Republic of Albania. Although the great constitutional reform of 2016, seemed to undertake through non-political constitutional bodies to solve the problems that are often created through bodies of a political nature, this so far has not yielded the expected results. The opposite has happened, the non-political constitutional body, which has a role in the appointment of judges of the Constitutional Court seems to have further fueled the conflict between the constitutional bodies in this process. The Judicial Appointments Council seemed like a finding in the 2016 constitutional reform, but from a body that would avoid disagreements dictated by the past of co-operation of constitutional institutions, it seems to have done the opposite. Sincere cooperation between constitutional bodies in fulfilling their obligations has been lacking in Albania since the advent of political pluralism in the early 199os, and this has not been achieved even by bodies created specifically for this purpose. In this way, the conflict between the President of the Republic and the Parliament, although perhaps dictated by political motives, has left the Republic of Albania without a functioning Constitutional Court. This paper aims to analyze that the lack of trust between the constitutional bodies of the Republic of Albania remains an obstacle in consolidating the rule of law in this country. It is also intended to analyze that the non-functioning of the Constitutional Court has brought a number of problems for achieving this goal, even to resolve conflicts between constitutional bodies.
\end{abstract}

Keywords: Constitutional Court, President of the Republic, Parliament, Judicial Appointments Council

\section{Introduction}

The choice of a judicial body to check the constitutionality of laws, not by the constitutional body that approves them, is certainly a feature of modern constitutions and dates back to the 1920. This 
constitutional body that would check the constitutionality of laws was conceived by the eminent jurist Hans Kelsen. Hans Kelsen, considered a "constitutional engineer" for the first Austrian Republic, was the originator of the Constitutional Court. In the latter, the well-known jurist saw the application and expression of a legal mentality which aimed at returning the political moment within the networks of a strict and abstract rationality (Lagi 2006, p.165).

Hans Kelsen viewed in the Constitutional Court a body that could create barriers to parliament by considering any act against the constitution as a null act, and as such should be avoided by its judges (Mezzetti 2007, p. 37 et seq.). In this sense, Hans Kelsen had a different point of view from other prominent jurists, such as Carl Schmitt. Hans Kelsen's view consisted in the fact that he thought that the Constitutional Court did not perform jurisdictional functions that apply individual norms, but could instead be defined as a negative legislator applying general norms, intended to repeal norms dictated by the Constitution (Capotosti 2016, p. 3).

The fine line between a "judicial" constitutional court and a constitutional court that may also take on a political role may be related to the fact that the long list of values and rights enshrined in the Constitution (Broglio 2000, pp. 333-370). The origin of the value of constitutional judgments dates back to 1610 in Great Britain, precisely in the common law system following the Kelsenian model, which aims to avoid the political majority violating the constitution to the detriment of the political minority (Palici 2016, p. 2). In fact, according to Kelsen, the review of the constitutionality of a law is nothing but a form of exercise of legislative power, with the only difference that the one exercised by the Constitutional Court is "Negative" and limited in quantity (Bisogni 2018, p. 377).

As mentioned above, there has been debate over the existence of a constitutional body composed of professionals who would judge the political will of the representatives. These debates have not been felt and have not existed in Albania due to the fact that this body has been set up among the last, compared to other European countries. So, if almost all countries had adapted to the Kelsenian theory on the external constitutional control of sub-constitutional norms, in Albania this control had existed for decades by the body that approved the legal norms. In this context, it is worth noting that in the communist system, the Constitution was seen more as a political program than as a normative act with the highest power in the state (Omari 2004). Thus, only theoretically it can be accepted that whoever passed the laws, also exercised their control, because in practice this seems like a paradox.

Thus, for many years in communist Albania, the theory of the control of the constitutionality of laws by the constitutional body that approved them based on the supreme power of the parliament, as the representative of the people had prevailed (Sadushi 2004). The innovation that came to Albania in the early 1990 according to the Kelsenian model seems to have been welcomed by the Albanian society which, although seeking political pluralism, seems to appear distrustful of the political power. The review of the constitutionality of laws in Albania was not based on either the Kelsenian model or the Schmitjan model. According to Schmitt, the defender of the Constitution cannot be identified as a considerable supervisory power of the Supreme Court, which, within a "Jurisdictional State", protects, in the form of due process, the bourgeois economic and social order (Capotosti 2016, p. 4).

Bringing to attention the different views of two prominent jurists regarding the control of the constitutionality of sub-constitutional legal norms is intended to recall that this debate took place almost a century ago. These perspectives therefore, aim to highlight the need for a body that should judge the constitutionality of the actions of political power. This debate needs to be reminded that beyond the differences of views, there is a common point related to the need for the existence of a constitutional body that would make the final interpretation of the constitution, which can in no way be a legislative body.

The Constitution of the Republic of Albania has already sanctioned that the final interpretation of the constitution and the control of the compliance of the laws with it, is done by the Constitutional Court. This raises the problem of the non-functioning of the Albanian state according to the constitutional provisions, which in order to keep the political activity on the constitutional rails, is not able to establish a normal functioning of a body to judge the political activity of the ruling majority.

The debate on strong political divergences between the majority and the minority is not new and 
these divergences can at least be controlled by a third party, which in this case is the Constitutional Court. Contrary to what was provided by Article $67^{1}$ of the Constitution of the Republic of Albania of 1976 , that the interpretation of the constitution was done by the parliament, it must be said that it was a parliament that had no political majority or minority. In this context, unlike in the past, there is political pluralism in Albania today, so the Constitutional Court can also serve as a guarantee for the minority when it cannot oppose the political decision-making of the majority with the forces of numbers.

The only constitutional body that can challenge the decision-making of the majority is the President of the Republic, who has returned for consideration most of the laws that have come to him from the ruling majority, to be enacted. This power is limited and can affect only the time it takes for the legal norm to enter into force and does not have its canceling power because the political majority in most cases has overturned the decrees of the President of the Republic to review the parliamentary norms. In this way, the constitutionality of legal norms has remained for more than three years in the evaluation of the body that approves them and the constitutional body that decrees them.

Today's constitutional conflict or political debate is precisely between the President of the Republic and the Parliament, for the non-functioning of the Constitutional Court. According to the Constitution, both the President of the Republic and the Parliament must each appoint three judges to the Constitutional Court. These appointments must go through a constitutional body which aims to unblock situations, which may hinder the appointments of members of the Constitutional Court. At the same time, the constitutional amendments of 2016 aimed at creating a Constitutional Court not part of political views, as was the case before the reform, where its members were appointed by the President of the Republic with the consent of Parliament. This way of forming the Constitutional Court was highly dependent on the relations of the President of the Republic with the ruling majority.

The new way of forming the Constitutional Court after the 2016 constitutional reform in Albania provided for the selection of candidates by the Judicial Appointments Council. This seems to have freed the Constitutional Court from political influence and conflict, but the Judicial Appointments Council not only did not serve this purpose, but instead managed to bring the President of the Republic into conflict with the Parliament. This conflict should have been resolved only by the Constitutional Court and in the absence of its functioning, then the solution in the form of advice and not the final decision, can only come from the Venice Commission². The Parliament of Albania and the President of the Republic addressed the latter regarding this issue, as the only institution that could bring the institutional dialogue so necessary for the functioning of the rule of law in Albania.

\section{How Long will the Constitutional Court of Albania Function?}

It has already been several years that the Constitutional Court of the Republic of Albania is out of function, in the implementation of the constitution to make its final interpretation. Albania, unlike many other European countries, has a short experience of the existence of the Constitutional Court. This is due to the fact that before political pluralism, as mentioned above, the interpretation of the constitution was done by the parliament itself.

However, the establishment of the Constitutional Court in the Republic of Albania is seen as a great achievement for the Albanian system after the fall of the communist system in the early 199os, as a victory of the democratic system to consolidate the rule of law (Omari-Anastasi 2010, p. 413).

\footnotetext{
${ }^{1}$ Article 67 of the Constitution of the Socialist People's Republic of Albania, approved by Law no. 5506, dated 28.12.1976: “The People's Assembly has the following main competencies: Determines, in accordance with the general line and directives of the Albanian Labor Party, the main directions of the internal and foreign policy of the state; Approves and amends the Constitution and laws, decides on the compatibility of laws with the Constitution and makes their interpretation (...); Decides on popular referendums; (...).

${ }^{2}$ European Commission for Democracy Through Law (Venice Commission).
} 
It was never thought at the time that the fragile Albanian democracy would face the lack of such an important constitutional institution in defense of the fundamental law of the state. In this context, it is worth mentioning that "The Constitutional Court is the guardian of the pactum societas, the guarantee of the common minimum conditions of collective life. It's the protection of constitutional principles on which 'no vote can be taken' "(Zagrebelsky 2004, p. 4).

Paradoxically, the non-functioning of the Constitutional Court of Albania would arise at a time when Albania, supported by the European Union and the United States of America, would undertake the most important reform, that of the justice system reforming. The implementation of this reform was based on the vetting process, which began to apply precisely to the members of the Constitutional Court. This process is also the first step in the transition of reforming the Constitutional Court in accordance with the reform.

The vetting process consists of the transitional control of all judges and prosecutors in the Republic of Albania (Hasanaj 2020, p. 490; Bozheku 2016, p. 19 et seq.). This control, except in cases of resignation of members of the Constitutional Court whose mandate had ended or for personal and health reasons, consisted of a demolition of this institution. The Constitutional Court continued for a long time with only one judge, and thus without an opportunity to make decisions, even for the review of the case in advance by a panel of 3 judges according to point 1 of article 31 of its organic law 3 .

For a long time, it seemed superfluous to claim the possibility of the Constitutional Court for a fundamental decision-making on matters. According to point 1 of article 32 of the organic law of the Constitutional Court, the latter convenes in plenary session with the participation of at least 6 of its Judges, and to date it consists of 4 Judges. The final decision to adjudicate a case in plenary was taken in 2018, and it remains unclear today when the Constitutional Court will resume adjudicating the merits.

The formation of the Constitutional Court has passed from the system provided by the Constitution of the Republic of Albania in 1998 through its appointments by the President of the Republic with the consent of the Parliament in the appointment according to the 2016 reform by three constitutional bodies. The constitutional reform regarding the Constitutional Court, although maintaining the number of previous provisions, determined a new way of appointing its members. Thus, out of the 9 members that form the Constitutional Court, 3 will have to be elected by the Parliament, 3 will have to be appointed by the President of the Republic and 3 will have to be elected by the Supreme Court.

Considering that for the first two institutions some actions have been taken to fulfill their constitutional obligations in the election or appointment of members of the Constitutional Court, for appointments by the Supreme Court, it is not even thought for the process to start within a short time, much less for it to end. This is because the Supreme Court itself is going through a long phase of resumption after the consequences caused in this court by the vetting process.

The reform of the justice system in the Republic of Albania aimed at achieving an independent system, but the result so far is the paralysis of the justice system (Hasanaj 2020, p. 496) and the lack of functioning of the Constitutional Court. The latter, contrary to what is provided by the Constitution for the resolution of conflicts between powers, turned itself into a reason for conflict between powers. The independence of the system, at least as far as the Constitutional Court is concerned, would depend mostly on the fact that its composition would already be created through different wills, moving away from the political will.

Unlike the members of the Constitutional Court who must be elected by the Supreme Court, for whom, as noted above, the road to a solution is still long, their election or appointment by the Parliament or the President of the Republic seems simpler. The reform of the justice system, in terms

3 Law no. 8577, dated 10.2.2000, amended by law no. 99/2016, "On the organization and functioning of the Constitutional Court of the Republic of Albania". 
of the formation of the Constitutional Court, had taken into account the low willingness of cooperation between constitutional institutions and the lack of a practice in the material implementation of constitutional norms. This way, some mechanisms were envisaged, which would have to consist in the automatic unblocking of the deadlocks created intentionally by these institutions in fulfilling their constitutional obligations. The practical implementation of these unblocking mechanisms in the Albanian state not only did not achieve its goal, but achieved the opposite by introducing into a constitutional conflict the institution of the President of the Republic with the Albanian Parliament.

This is related to the provision of an ad hoc selection institution, which after the announcement of vacancies by the naming institutions would have to make the selection between the candidacies. As mentioned above, this institution is the Judicial Appointments Council ${ }^{4}$, which consists of 9 members who come from the courts and the prosecution and have a one-year term 5 . In this process, this institution must select the candidates who apply for the vacant position in the Constitutional Court, it must select at least three by ranking them according to a score ${ }^{6}$. In this way, if the naming institution did not take the next step, the first ranked candidate would be automatically elected and from elected it would then become selected.

But, from the point of view of the interaction of these institutions, the Judicial Appointments Council, from a proposing and selecting institution for candidates, seems to have turned into an institution which has determined the election of candidates for members of the Constitutional Court. Thus, the implementation in practice of the provisions that aimed to change the way the Constitutional Court was formed and consequently one more opportunity for it to get out of politics, it ended up in a process that centralized it as a single institution. At this point you can hardly talk about an independence of the institution guaranteeing the final observance and interpretation of the Constitution.

\section{Election of Members of the Constitutional Court between the Parliament and the President of the Republic}

The selection of Constitutional Court judges, from a process that should have avoided deadlocks due to the lack of a constitutional practice of dialogue of constitutional institutions, has resulted in a process that fueled the constitutional conflict. In a country where the principle of democracy and the principle of the rule of law are functional, this constitutional conflict would be resolved precisely by the Constitutional Court. It is indisputable that the latter has played a role in strengthening the rule of law and consequently in respecting human rights, which is considered as a guarantee principle (Zaganjori et al. 2011, p. 170). The human rights that the Constitutional Court must guarantee, come as a constitutional guarantee in the preamble of the constitution of Albania, where it is determined that

\footnotetext{
${ }^{4}$ Article 149 / d paragraph 1 of the Constitution of the Republic of Albania: "The Judicial Appointments Council verifies the legal conditions and evaluates the professional and moral criteria of the candidates for High Inspector of Justice, as well as the candidates for members of the Constitutional Court. The Judicial Appointments Council reviews and ranks candidates according to professional merit. The ranking of the candidates is not obligatory, except when the candidate cannot be appointed".

${ }^{5}$ Article 220 of Law no. 115/2016 "On the governing bodies of the justice system:" 1. The Judicial Appointments Council consists of 9 members as follows: a) two judges of the Constitutional Court; b) a judge of the High Court; c) a prosecutor from the General Prosecutor's Office; ç) two judges from the courts of appeal; d) two prosecutors from the prosecutor's offices at the courts of appeal; $d h$ ) a judge from the administrative courts. 2. The members of the Judicial Appointments Council remain in office for 1 year from January 1 of each calendar year. 3. In case of impossibility or conflict of interest, the members are replaced by the replacement members.

${ }^{6}$ Article 125 point 1 of the Constitution of the Republic of Albania: "The Constitutional Court consists of 9 members. Three members are appointed by the President of the Republic, three members are elected by the Assembly and three members are elected by the Supreme Court. The members are selected from among the candidates ranked in the first three places of the list by the Judicial Appointments Council, according to the law. "
} 
they serve as necessary conditions for building democracy (Cukani 2016).

The Constitutional Court was out of order and the Albanian constitutional institutions, unable to have a dialogue on prevention, but above all on resolving the deadlock, turn to the Venice Commission. If the decisions of the Constitutional Court are binding to be implemented according to Article 132 of the Constitution, the positions of the Venice Commissions, although important from a doctrinal point of view, have no binding force, but are mostly interpreted at the will of the institutions by maintaining and even reinforcing the attitudes which they had had before the institutional conflict arose.

In this way, in the hope of establishing a Constitutional Court, although incomplete, the process of appointing some judges of this Court took place in 2019. But in this process a constitutional problem arose that the same list of candidates was addressed to both the parliament and to the President of the Republic This happened without following a certain order under Article 179 of the Constitution. In fact, Article 179 point 2 of the constitution stipulates that "The first member to be replaced in the Constitutional Court is appointed by the President of the Republic, the second is elected by the Assembly and the third is appointed by the Supreme Court. This turn is followed for all appointments that will be made after the entry into force of this law. Failure to follow this constitutional deadline by the Judicial Appointments Council and the same list of candidates as the President of the Republic and the Parliament, led the Judicial Appointments Council to dictate the appointing and selecting power of the members of the Constitutional Court according to constitutional provisions.

To resolve grievances over the role of the Judicial Appointments Council and the conflicts that the latter had created between the President of the Republic and the Parliament, as mentioned above these two institutions addressed the Venice Commission. Thus, on December 30, 2019, the Speaker of the Parliament of the Republic of Albania addresses the Venice Commission with a set of several questions regarding the process of appointing members of the Constitutional Court and waiting for an answer to resolve the situation. The President of the Republic did the same, feeling ignored by the Council of Judicial Appointments, publicly expressing his dissatisfaction through these requests for public opinion, listing the entire chronology of the selection process of the members of the Constitutional Court ${ }^{7}$.

3.1 The constitutional role of the Judicial Appointments Council in the formation of the Constitutional Court and as a mechanism to resolve any obstacles in this process

The Constitution of Albania amended in 2016, keeping in mind the fight that took place in the past between the President of the Republic and the Parliament for the appointment of members of the Constitutional Court had found a different mechanism for their appointment. But the good intentions of justice reform have led to the lack of an institutional arbitrator (Bozheku 2019, p. 46) who can resolve such frequent conflicts between the authorities in Albania.

Thus, in the selection of candidates after the announcement of candidacies by the constitutional body for the vacant position, the list of applicants would be sent to the Judicial Appointments Council. The latter is conceived as an institution that represents an unblocking mechanism when any of the constitutional bodies could not select the name dictated the election of a member of the Constitutional Court by unblocking the process. This unlocking, has without question, more value in the case of appointments by collegial bodies such as the Supreme Court and Parliament, but not in the case of the appointment of a Judge by the President of the Republic. But even in the latter case, when the President does not exercise his constitutional role, as a rule it should be a distant hypothetical case, then the unlocking mechanism may apply.

On the other hand, it is worth noting that the prediction of many constitutional bodies could lead

7 See the letter addressed by the President of the Republic to the President of the Venice Commission Gianni BUQUICCHIO, on 21.01.2020 at http://president.al/wp-content/uploads/2020/o1/Letra-e-Presidentit-t\%C $3 \% A B$ Republic\% C $3 \%$ ABs-p\% C3\% ABr-Commission-of-Venice-1.pdf. visited on September 11, 2020. 
to constitutional blockages which could not be easily resolved (Spangher 2017, p. 23 et seq.), But to achieve such a long absence in the functioning of the Court Constitutional, it can be said that no one had foreseen it.

The opinion of the Venice Commission regarding the role of the Judicial Appointments Council for the appointment of judges of the Constitutional Court shows a lack of transparency with the timing of the transmission of the lists to the nomination bodies (Venice Commission 2020, pp. 17-18, §90, 92).

Logic requires that the unlocking mechanism of the Judicial Appointments Council should apply most to the election of judges by the Collegiate bodies, but in any case, the judge begins his term only after taking the oath before the President of the Republic. This is where even the distant hypothetical case about the President of the Republic can become a reality.

In any case, as mentioned above, the Judicial Appointments Council was conceived by the legislator as the guarantor of the process and not as a selection mechanism, which was clearly demonstrated when it seemed that the Constitutional Court was moving towards its functional formation. It is emphasized functional, because it is still too early to say in full because as mentioned above three judges of this court are elected by the Supreme Court.

Returning to the Judicial Appointments Council, it can be said that this institution seemed to receive the constitutional right to vote when, perhaps dictated by the same candidates for some vacant positions, it sent the same candidacies to the President of the Republic as well also to Parliament (Venice Commission 2020, pp. 18-19, §96). This led to a major constitutional debate between the President of the Republic and the Parliament in Albania. This debate was accompanied by some constitutional paradoxes, where at this point Albania does not need to copy models as usual, but is quite original.

The situation went to the point where the President of the Republic refused to accept the oath of an automatically elected member because he had contested the selection of candidates by the Judicial Appointments Council. This was not the end of the paradox, as the now automatically appointed Judge was sworn in before a notary public since the President of the Republic had not fulfilled the ceremonial obligation of swearing. The ceremonial obligation of judges before the President of the Republic is not, in fact so ceremonial as long as he covers a constitutional function as guarantor of the constitution. Ultimately this remains a Constitutional provision, even though it is fulfilled through a seemingly formal act.

In conclusion, the opinion of the Venice Commission underlines the need for cooperation and inter-institutional dialogue for the return to function of the Constitutional Court and the Supreme Court. The Venice Commission also cites an expression of its President in the report in which it states that "Democratic culture and maturity require institutional content, trust and mutual respect between state institutions."

\section{Problems Caused by the Non-Functioning of the Constitutional Court in Albania}

Although in a short tradition, the Constitutional Court of Albania had begun to strengthen its jurisprudence on many sharp constitutional issues starting from 1992 (Sina 2017, p. 53 et seq.). At the very least, its existence would resolve at least the above-mentioned institutional conflicts and even better if it would fulfill its constitutional obligations in protection of the constitutional rights of individuals.

The Constitutional Court of Albania was established in 1992 by adding a chapter to the law on "Main Constitutional Provisions" and was finally sanctioned in the Constitution of the Republic of Albania in 1998. Article 17 of the law establishing the Constitutional Court in the Republic of Albania stipulated that "the Constitutional Court is the highest authority, which protects and guarantees the observance of the Constitution and legislation, as well as makes the final interpretation of the Constitution". It is worth mentioning that in its beginnings the Constitutional Court of the Republic of Albania did not clearly understand its role as a "Negative" legislator that it covered by amending a paragraph of the Civil Code with decision no. 6 of 1992 (Omari 2004, p. 271). 
The Constitutional Court of the Republic of Albania with its jurisprudence has ruled on important constitutional principles as well as on constitutional human rights by giving decisions that have served for their consolidation in Albania (Zaganjori et al. 2012). This has made these principles and rights come to life and take on a certain value that can only come as a result of the interpretation made by the Constitutional Court. In a political climate with high sensitivity during the transition in Albania, the Constitutional Court, through some bold decisions has fulfilled its constitutional mission by contributing to the consolidation of a functioning democracy in accordance with the principle of the rule of law (Sadushi 2012, p. 109).

Because of the fact that in Albania, the Parliament as a representative body of the people within it is characterized by a political extremism between the majority and the minority, the Constitutional Court is perceived as a necessary constitutional body and guarantor of the minority. This fact is reinforced in the conviction of the sovereign with the fact that this body itself is composed of professionals, where their only interest seems to remain the interpretation of the Constitution. This perception of the sovereign on the controlling activity of the Constitutional Court over the Parliament, which in itself is representative of the people, is also related to the fact that the court itself is a guarantee on electoral deviations that the representative usually makes in an unconsolidated democracy like Albania. In this context, it is worth mentioning that the legitimacy of the Constitutional Court in Albania has found support from observers and actors both outside and inside Albania (Sadushi 2012, 108).

So, the non-functioning of this constitutional body has caused the sovereign himself to lose trust in their representatives, because this relationship has been set up and maintained mostly by a spirit of mistrust between them. And specifically, this distancing of the relations between the representatives and the represented could be flattened by the guarantee that can be placed, exactly by the Constitutional Court.

It should be noted that the lack of functioning of the Constitutional Court came as a result of the vetting process which was dictated by the lack of public trust in the institutions of the justice system. And all this, did not alleviate this lack of trust, but rather added to it. At least until today when, despite the advice of the Venice Commission, the Albanian institutions have not found the common language of sincere cooperation to pass this stage of non-functioning of the Constitutional Court.

\section{Conclusion}

Through this paper it is requested the analyzation of the lack of cooperation between the constitutional institutions in Albania, for the establishment of the Constitutional Court as the highest constitutional body that makes functional the principle of the Rule of Law. Albania has recently embraced the Kelsenian model of controlling the constitutionality of laws through a judicial body. Although belated in its creation, it had managed to balance the fragile balances between the revenge of the ruling majority and the opposition of the minority by catching several times in the web of the constitution the legal norms that contradicted it. Thus, a situation almost on the verge of constitutional absurdity between the constitutional institutions for the formation of the Constitutional Court, would have to be resolved precisely by the Constitutional Court.

In the absence of the latter functioning, the two constitutional bodies that were in conflict over the joint candidates turned to the Venice Commission. This does not seem to have happened to resolve the institutional conflict, because this credible institution does not have this constitutional right, but rather to seek a legitimacy of the actions of each body by an international institution. It turns out to be an absurd conflict between the President of the Republic and the Parliament when the candidates had run for both the vacancy announced by the Parliament and the vacancy announced by the President of the Republic. Without undertaking to evaluate the actions of the Judicial Appointments Council, it can be said that he dominated the two institutions that had the right to appoint judges of the Constitutional Court by passing to himself powers that he did not have. These competencies are paradoxically exceeded when the Judicial Appointments Council, by a body designated as a selector for the vacancies 
announced by the nomination institutions, turned into an electoral body while presenting the same candidates to both nomination bodies at the same time. Thus, it can be said quite clearly that at least so far, the judges of the constitutional court have not been elected by the President of the Republic and the Parliament. but by the Council of Judicial Appointments.

This paper highlights that although attempts were made to depoliticize the selection process of the Constitutional Court because it ultimately serves as a net against politics, the reality of implementing the reform has demonstrated the opposite. This has led to the absence of the Constitutional Court for several years and what is most damaging is that there is not yet known a date that can make the Constitutional Court in Albania functional. This is due to the fact that although the Judicial Appointments Council failed to avoid the impossible conflict between the President of the Republic and the Parliament, these institutions appoint each 3 members to the Constitutional Court to form a sufficient quorum for its decision-making. This does not mean that with six members the Constitutional Court can function regularly because 3 of its members come as an election of the Supreme Court, which also seems to have a distant day of its creation. Only when fully formed, will the Constitutional Court be able to function and decide regularly. This will be achieved when the three Constitutional bodies, for its formation, should have appointed each of the three members as provided by the Constitution. In conclusion it can be said that the constitutional changes of 2016 were conceived to avoid conflicts that the reform of the justice system thought it had closed with its realization. These changes were, without question, related to the unconsolidated tradition of constitutional institutions in Albania, but it seems that even after the reform of the justice system, they have left shadows even today, more than four years after the 2016 constitutional reform in Albania.

\section{References}

Alberto Capotosti, P., (2016). La Giustizia Costituzionale e il suo Insegnamento, in Nomos Le Attualità nel Diritto, Inediti Nomos, 2, p. 3.

Bisogni, G., (2018). Il Controllo Di Costituzionalità Secondo Luigi Ferrajoli: “Auctoritas" O "Veritas Facit Iudicium”?, in Diritto e Questioni pubbliche - 18 XVIII/1, p. 377.

Bozheku, E., (2016). La riforma costituzionale ("strutturale) del sistema della giustizia nella Repubblica d'Albania, in Dirirtto Penale Contemporaneo, www.dirittopenalecontemporaneo.it, p. 19 et seq.

Bozheku, E., (2019). Riforma della giustizia (in crisi), empasse istituzionali e sogni europei. Le "pericolose" crocevie d'Albania in Illyrius, 12, p. 46.

Cukani, E., (2016). La costituzionalizzazione dei diritti fondamentali nell'Albania postcomunista in Consulta Online, Fasc. 1.

European Commission for Democracy Through Law (Venice Commission), Albania opinion on the appointment of Judges to the Constitutional Court Adopted by the Venice Commission on 19 June 2020 by a written procedure replacing the 123rd plenary session, p. 17-18, §9o, 92.

Hasanaj. Sh., (2020). L'Albania al bivio di un compromesso: la riforma della giustizia albanese e l'apertura dei negoziati con l'Unione europea in AIC-Osservatorio Costituzionale, Fasc. 3, p. 490 ss.

Lagi, S., (2006). Kelsen e la Corte costituzionale austriaca: un percorso storico-politico (1918-1920), in Giornale di Storia Costituzionale, 11, p. 165.

Law no. 115/2016 "On the governing bodies of the justice system".

Law no. 5506, dated 28.12.1976 "Constitution of the People's Socialist Republic of Albania" abrogated.

Law no. 7561, dated 29.4.1992 For some changes and additions to the law no.7491, dated 29.4.1991 "On the Main Constitutional Provisions".

Law no. 8417, 21.10.1998 "The Constitution of the Republic of Albania", Amended.

Law no. 8577, dated 10.2.2000, amended by law no. 99/2016, "On the organization and functioning of the Constitutional Court of the Republic of Albania".

Margiotta Broglio, C., (200o). La Corte costituzionale italiana e il modello kelseniano, in Quaderni costituzionali, Rivista italiana di diritto costituzionale, 2, pp. 333-370.

Mezzetti, L., (2007). La giustizia costituzionale, Padova, Cedam, p. 37 et seq.

Omari, L., (2004). Shteti i së Drejtës, Tiranë, Elena Gjiko.

Omari. L., Anastasi, A., (2010). E Drejta Kushtetuese, Tiranë, ABC. p. 413.

Palici di Suni, E., (2016). Tre modelli di giustizia Costituzionale, in AIC-Rivista, 1, p. 2. 
Sadushi, S., (2004). Kontrolli Kushtetues, Tiranë, Botimpex.

Sadushi, S., (2012). Drejtësia Kushtetuese në zhvillim (trajtime teorike dhe të praktikës së gjykimit kushtetues, Tiranë, Botime Toena, p. 109.

Sina, A., (2017). L'uso della comparazione nella giustizia costituzionale albanese, in Saggi - DPCE on line, 1, p. 53 et seq.

Spangher, G., (2017). Brevissime considerazioni sulle modifiche del Sistema giudiziario in Albania, in AA. VV., La riforma costituzionale ("strutturale") della giustizia nella Repubblica d'Albania (a cura di Bozheku - Spangher - Hoxha), Roma, 2017, p. 23 et seq.

Zaganjori, Xh., Anastasi A., Cani (Methasani), E., (2011). Shteti i së drejtës në Kushtetutën e Republikës së Shqipërisë, Tiranë, Adelprint, p.17o.

Zaganjori, Xh., Vorpsi, A., Biba, D., (2012). Parime kushtetuese dhe të drejta themelore në jurisprudencën e Gjykatës Kushtetuese, Tiranë, Adel Co.

Zagrebelsky, G., (2004). La Corte in-politica, intervento - XXIII Premio Chiarelli, Roma 20 ottobre 2004, in Federalismi.it, 21, p. 4 . 